\title{
Characterization of Apple mosaic virus isolates detected in hazelnut in Poland
}

\author{
Mirosława Cieślińska ${ }^{1} \cdot$ Natallia Valasevich $^{2}$
}

Received: 18 November 2015/Accepted: 31 May 2016/Published online: 28 June 2016

(c) The Author(s) 2016. This article is published with open access at Springerlink.com

\begin{abstract}
Apple mosaic virus (ApMV) infects over 65 plants species of Rosaceae family including hazelnut. The virus causes chlorotic or yellow patterns, rings and mosaic symptoms on the leaves and losses in yield of nuts. The occurrence and genetic diversity of ApMV were evaluated in 14 plantations of hazelnut in Poland. A total of 13 of 125 hazelnut samples tested positive for ApMV using ELISA and reverse transcriptase-polymerase chain reaction. Several primer pairs were used for RT-PCR to amplify the coat protein (CP) and movement protein (MP) genes as well as complete RNA-3 of the ApMV. Genetic diversity was observed in full-length sequences of RNA-3 of the ApMV isolates from hazelnut. The similarity of nucleotide sequence of the CP and MP genes of the isolates was 90.3-99.9, and $87-99.7 \%$, respectively. Phylogenetic analysis showed that ApMV isolates from hazelnut grouped separately from the virus strains found in other plant species.
\end{abstract}

Keywords ApMV - Coat protein · Movement protein . Phylogenetic analysis

\section{Introduction}

Apple mosaic virus (ApMV) is a member of the subgroup III of the genus Ilarvirus, Bromoviridae family. This virus occurs worldwide and infects a number of

Mirosława Cieślińska

Miroslawa.Cieslinska@inhort.pl

1 Department of Plant Protection, Research Institute of Horticulture, Konstytucji 3 Maja 1/3, 96-100 Skierniewice, Poland

2 Department of Biotechnology, Institute for Fruit Growing, Samochvalovichi, Belarus woody and herbaceous plants in over 65 species in 19 families including apple, hazelnut, strawberry, apricot, black cherry, almond, red currant, raspberry, rose, birch, chestnut, and hop $[4,10,14,26,28]$. ApMV is transmitted by vegetative propagation of infected plant material and by mechanical inoculation [5]. No natural vector of the virus is known [20]. ApMV causes either chlorotic or yellow patterns, rings and mosaic observed during mild temperatures on the leaves of hazelnut (Corylus avellana L.) or infected plants do not show any symptoms. ApMV causes significant yield reductions in hazelnuts (up to $42 \%$ ) and infected trees showed a slight growth reduction $[1,3]$. The hazel mosaic symptoms were first reported in Bulgaria [7]. The incidence of ApMV on hazelnut plantations has been reported in Turkey [1], Spain [3], USA [21], and Italy [22]. The previous study using ELISA assay showed that ApMV occurred in hazelnut grown in several plantations mostly in south-eastern Poland [13, 19].

Single-stranded RNA of the ApMV genome consists of three segments: RNA-1, RNA-2, and RNA-3 (3.4, 2.9, $2.0 \mathrm{~kb}$ size) [23, 24]. RNA-3 has two open reading frames from which the first encodes the putative movement protein (MP, $861 \mathrm{nt}$ ) and the other translates coat protein $(\mathrm{CP}, 672 \mathrm{nt})$ by producing a subgenomic mRNA [2]. Molecular diversity of ApMV isolates from different geographical regions and plant species has been revealed on the basis of sequence analysis $[11,14,15,17,18$, 27].

The aim of the study was to characterize the molecular properties of ApMV isolates from hazelnut and to evaluate the presence of possible genetic diversity of the virus strains found in Poland based on the MP and CP gene sequences and their relationships with previously studied strains. 


\section{Materials and methods}

Hazelnut plants growing in 14 commercial plantations as well as in home gardens and natural environment located in eight regions of Poland were surveyed for symptoms of apple mosaic disease in 2010 and 2012. A total of 125 leaf samples (56 in 2010 and 69 in 2012) were collected from symptomatic and asymptomatic hazelnut plants of different cultivars (Table 1). The samples were tested by DASELISA for Apple mosaic virus using a commercially available polyclonal antibody kit (Loewe Biochemica, Germany).

The silica capture (SC) method [8] was used for extraction of total nucleic acids from leaf samples in which the virus had been detected by ELISA. One-tube reverse transcription-polymerase chain reaction (RT-PCR) was conducted using SuperScriptIII ${ }^{\mathrm{TM}}$ One-Step RT-PCR with Platinum ${ }^{\circledR}$ Taq (Invitrogen). Primer sets ApMVup1061/ ApMVd1845 [27] and ApMVup/ApMVd [14] were used to amplify the CP and MP genes of ApMV, respectively. Amplification products were separated by electrophoresis in $1 \%$ agarose gel and, after staining with ethidium bromide, were visualized under UV light.

The complete RNA-3 of ApMV which covered both MP and $\mathrm{CP}$ genes was synthesized using two pairs of primers: 3ApMV20F/3ApMV1031R and 3ApMV888F/3ApMV203 $5 R$ [27]. The resulting amplicons were purified, sequenced and analyzed using Lasergene 7.1 software (DNASTAR). The phylogenetic tree was calculated by the neighbor joining method with the maximum composite likelihood

Table 1 Result of testing of the hazelnut samples for Apple mosaic virus

\begin{tabular}{llll}
\hline $\begin{array}{l}\text { Hazelnut } \\
\text { cultivar }\end{array}$ & $\begin{array}{l}\text { Number of } \\
\text { surveyed } \\
\text { plantations }\end{array}$ & $\begin{array}{l}\text { Number of } \\
\text { tested plants }\end{array}$ & $\begin{array}{l}\text { Number of } \\
\text { positively } \\
\text { tested plants }\end{array}$ \\
\hline Catalan & 7 & 23 & 0 \\
Webb's Prize Cob & 5 & 12 & 0 \\
Hall's Giant & 5 & 9 & 0 \\
Merville de Bollwiller & 3 & 5 & 0 \\
Syrena & 3 & 6 & 0 \\
Lambert's Red & 3 & 8 & 0 \\
Trapezunter & 2 & 6 & 6 \\
Barcelona & 2 & 5 & 0 \\
Cosford & 2 & 3 & 0 \\
Truchsess Zellernuss & 1 & 2 & 0 \\
Negret & 1 & 7 & 7 \\
Tonda di Giffoni & 1 & 2 & 0 \\
Waterloo & 1 & 2 & 0 \\
Lambert's White & 1 & 3 & 0 \\
Unknown cultivars & 6 & 33 & 0 \\
\hline
\end{tabular}

model and 1000 bootstrap replications in MEGA 4.0 program [25].

\section{Results}

In 2010, yellow patterns and mosaic symptoms were observed on the leaves of hazelnut plants 'Negret' (Fig. 1) growing in one of the surveyed plantations located in south-west Poland. Apple mosaic virus was detected by DAS-ELISA only in seven symptomatic plants of 'Negret'. The virus was not detected in any of the other cultivars. During the next inspection conducted 2 years later on the same plantations, similar symptoms were noticed also on 'Trapezunter' hazelnut growing in the same row with 'Negret' symptomatic plants. DAS-ELISA resulted in detection of ApMV in leaf samples not only from previously infected 'Negret' hazelnut but also from five 'Trapezunter' plants in which the virus had not been detected in 2010. A single positive sample of 'Trapezunter' was obtained from another plantation.

RT-PCR with ApMVup/ApMVd and ApMVup1061/ ApMVd1845 pairs of primers specific to MP and CP genes of the virus, respectively, resulted in amplification of the products of expected size (860 and $784 \mathrm{bp}$, respectively).

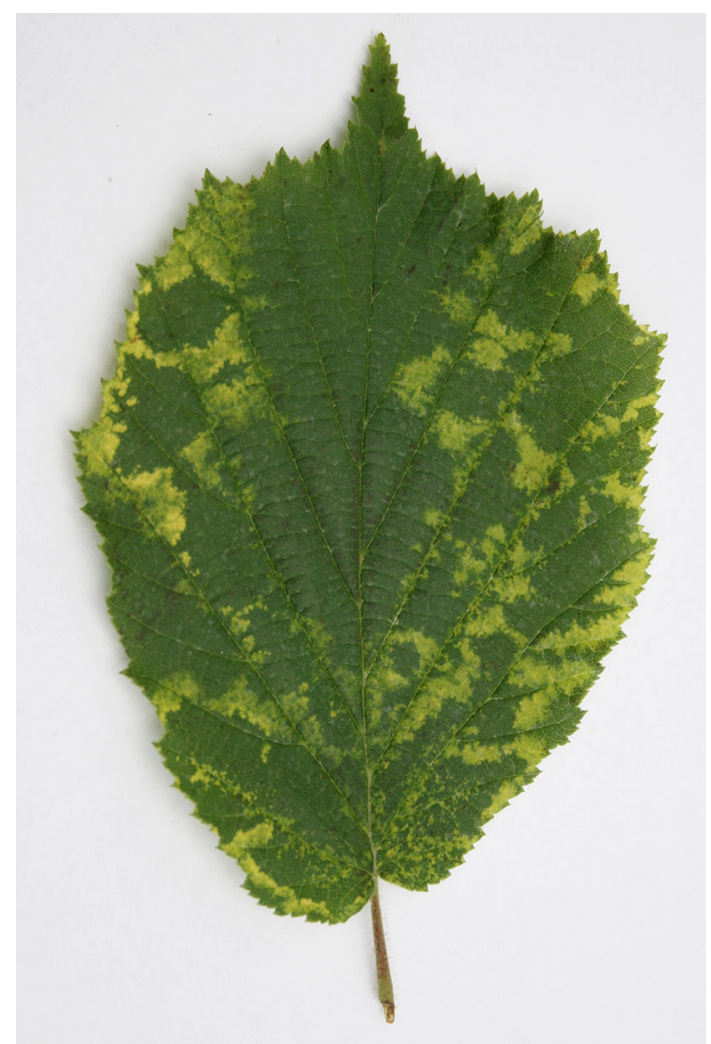

Fig. 1 Yellow line patterns and rings on the leaf of 'Negret' hazelnut infected with Apple mosaic virus 
Fig. 2 Neighbor-joining analysis showing predicted relationships between Apple mosaic virus isolates based on the nucleotide sequences of coat protein $(\mathrm{CP})$ gene fragment. Sequence of Prunus necrotic ringspot virus, PNRSV (acc. no. L38823) was used as an outgroup. Numbers represent bootstrap values out of 1000 replicates. Bootstrap values below $70 \%$ were collapsed

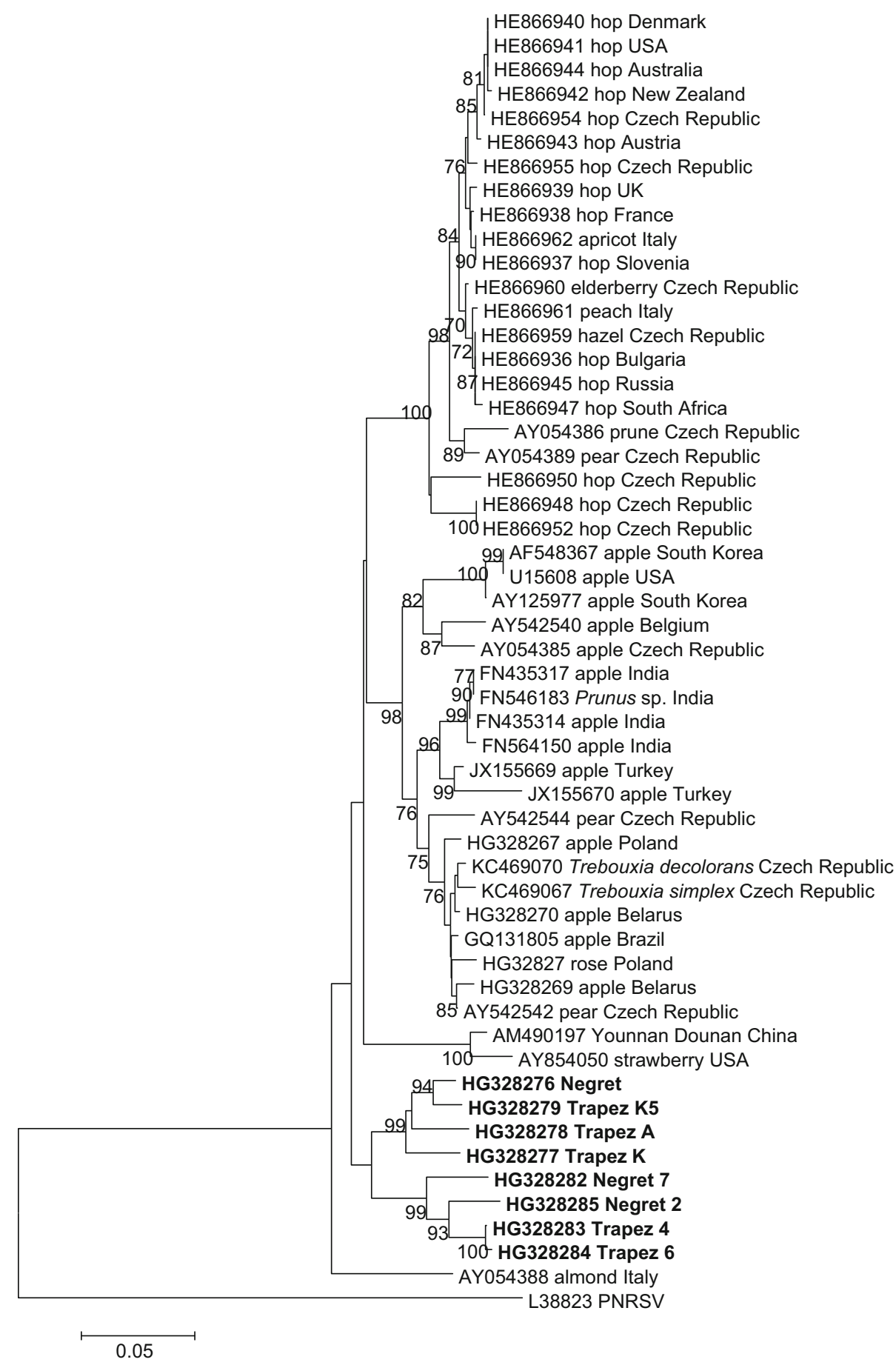

Five isolates of the virus from Trapezunter cv. (Trapez A, Trapez K, Trapez K5, Trapez 4, Trapez 6) and three from Negret cv. (Negret, Negret 2, Negret 7) hazelnuts were selected for sequence and phylogenetic analyses. The $\mathrm{CP}$ of the hazelnut isolates was 663-672 nucleotides (221-224 amino acids) in length. The ranges of pairwise nucleotide sequence similarity in the $\mathrm{CP}$ gene of ApMV isolates from hazelnut were 90.3-99.9 and 85.2-90.8\% when compared to corresponding sequences of the ApMV strains available in EMBL/GenBank database. The sequence of this genome fragment of the hazelnut isolates showed maximum identity with almond isolate from Italy (acc. no. AY054388). Phylogenetic analysis of CP gene showed that hazelnut isolates from Poland grouped separately from the virus strains from the other plant species including apple, pear, Prunus sp., rose, hop, Trebouxia sp. (lichen symbiotic algae), and elderberry (Fig. 2). They were also genetically different from the hazelnut isolate of 


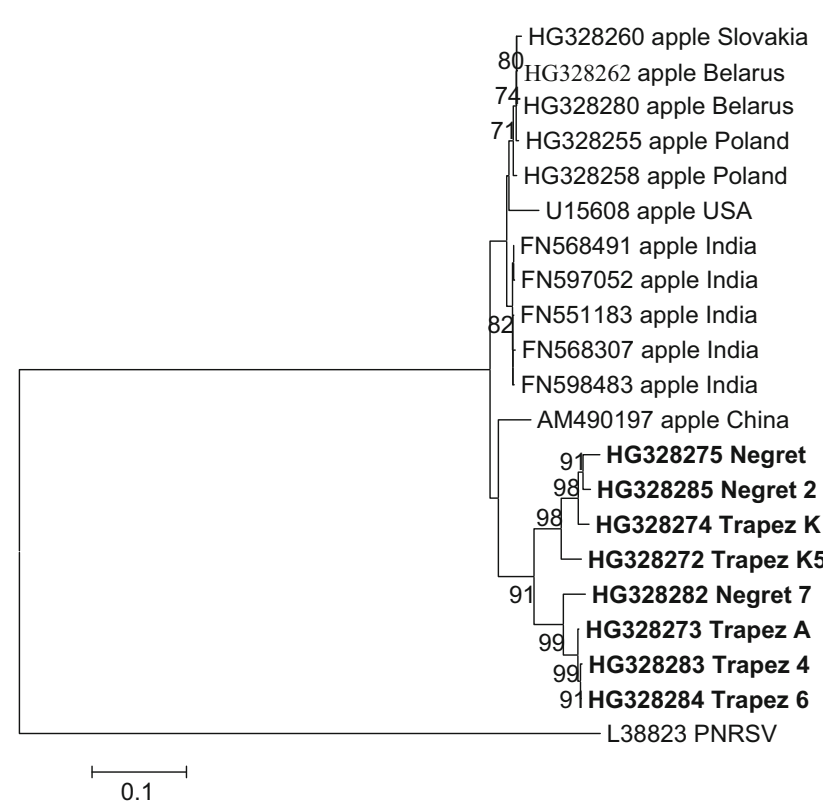

Fig. 3 Neighbor-joining analysis showing predicted relationships between Apple mosaic virus isolates based on the nucleotide sequences of movement protein (MP) gene fragment. Sequence of Prunus necrotic ringspot virus, PNRSV (acc. no. L38823) was used as an outgroup. Numbers represent bootstrap values out of 1000 replicates. Bootstrap values below $70 \%$ were collapsed

ApMV reported from the Czech Republic [11]. The 9-ntdeletion in position 155-163 (after 48 aa position) was found in the CP genes of Negret 2, Negret 7, Trapez 4 and Trapez 6 hazelnut isolates, while 6-nt-deletion in position 155-160 was present the sequences of Trapez A and Trapez $\mathrm{K}$ isolates. These deletions resulted in missing of 3 aa and 2 aa, respectively, in the putative translations of this fragment of RNA-3. The other specific fragment of the sequence in the $\mathrm{CP}$ region of the all eight analyzed hazelnut isolates was AAT $\rightarrow$ GGT substitution resulted in Asn $\rightarrow$ Gly change inside MVCKYCGHT (the zinc-finger) motif.

Sequence of $\mathrm{CP}$ gene of isolates Negret, Trapez K, Trapez A, Trapez K5 were deposited in GenBank under accession numbers HG328276-328279, respectively.

The MP gene of the hazelnut isolates was 858 nucleotides (289 amino acids) in length. Multiple alignment of the MP gene sequences showed the heterogeneity of the studied ApMV isolates. The eight hazelnut isolates shared 87.0-99.7\% similarity, while the level of identity of these isolates with apple strains from India, USA, China, Poland and Belarus deposited in GenBank was $86.0-89.4 \%$. The sequences of MP gene of the hazelnut isolates showed maximum identity with an apple isolate from China (acc. no. AM490197). Phylogenetic analysis of the MP gene showed that Polish hazelnut isolates formed a distinct cluster separated from apple strains from India, Poland, Belarus, Slovakia and USA (Fig. 3). Comparison of the putative amino acid sequences of the MP showed five substitutions which were unique for the Polish hazelnut isolates and several substitutions characteristic for hazelnut isolates and apple strain from China (acc. no. AM490197) only.

The sequences of the MP genome fragments ( $735 \mathrm{bp}$ ) of the isolates from Trapez K5, Trapez A, Trapez K, and Negret have been deposited in GenBank under accession numbers HG328272-328275, respectively. The nearly complete nucleotide sequences of RNA 3 (1934-1939 nt) of four ApMV isolates: Negret 7, Trapez 4, Trapez 6, Negret 2 were deposited in GenBank under accession numbers HG328282-328285, respectively.

\section{Discussion}

ApMV was detected in all 160 hazelnut cv. Negret orchards assayed in Catalonia, north-east Spain, in the last decade of twentieth century [5] which indicated that cv. Negret contributed to virus spread. Our study identified the virus also in the Trapezunter cultivar. The presence of ApMV in hazelnut germplasm in Poland from plant material of foreign origin was previously verified by ELISA method, but the virus had not been detected in Trapezunter cv., while Negret cv. plants were positively tested for ApMV [13]. During our study in 2010, the virus was not found in the samples collected from 'Trapezunter' growing in the same row with 'Negret' trees, while 2 years later its presence was confirmed in plants of the both cultivars. ApMV has been recently detected in naturally infected weeds in hazelnut orchards, and it was reported that the virus could spread via root grafting, weeds or an unidentified arthropod vector [6]. Furthermore, Akbaş and Değirmenci [1] suggested that transmission by foliar or root contact among trees in hazelnut shrubs may be a pathway of ApMV spread in commercial orchards. Foliar contact and root grafting also played role in spreading of this virus in hop plants and apple trees $[9,12,16]$.

The sequence analyses of MP and CP genes showed the genetic diversity of the ApMV isolates from hazelnut trees in Poland and allowed to establish their phylogenetic position separately from the other strains of the virus. Variability of the CP gene sequence of the ApMV isolates from different plant species and geographical origin resulted in their classification into separate clusters. There are several CP gene sequence-based ApMV classification systems clustering the virus strains into three [15] or five main subgroups [14]. Recently, Grimová et al. [11] proposed classification of ApMV isolates into two main clusters I and II divided into subclusters. This scheme seems to be not so clear since some virus strains like Italian PAM-ITA from almond (acc. no. AY054388), 
American NCGR 9026 from strawberry (acc. no. AY854050), and XX1-CHN found in unknown Chinese host (acc. no. AM490197) were not classified to any of these groups. The Polish isolates from hazelnut were also grouped separately from these both clusters on the phylogram. It is in the agreement of the previous studies which showed that there was no correlation between the CP gene sequence variability of the ApMV strains and their geographical origin.

Lee et al. [15] demonstrated that ApMV sequences of different isolates showed maximum variability in the first 300 nucleotides (100 amino acids) of the CP region. The gene sequences of isolates from different plant hosts including hop, peach, elderberry, apricot and hazelnut with the 15-nt-deletion after position 141 resulting in missing of 5 aa [17] were classified by Grimová et al. [11] in Ia subcluster. This deletion does not occur in the CP gene of Polish hazelnut isolates and in the sequence of the strains classified by Grimová et al. [11] into subclusters Ib, IIa and IIb. However, partial deletions of $9 \mathrm{nt}$ and $6 \mathrm{nt}$ were present after position 154 in the sequences of this region of hazelnut isolates from Poland. The 9-nt-deletion was also identified after position 150 in the sequence of PAM-ITA isolate from almond (acc. no. AY54388).

Moreover, in the sequence of hazelnut isolates, Asn $\rightarrow$ Gly change inside the zinc-finger motif was noticed as a consequence of AAT $\rightarrow$ GGT substitution. Grimová et al. [11] reported that the position Gly7 in the context MVCKYCGHT is characteristic for all the sequences from cluster I as well as for PAM-ITA and XX1-CHN isolates, while presence of Asn 7 in the same position is noticed in the sequences from cluster II. However, in contrast to the hypothesis of these authors, it seems that change inside this motif sequence is not associated with the specific cluster since PAM-ITA and XX1-CHN isolates sequences are significantly different from the sequences of ApMV strains classified to cluster I and the Polish hazelnut isolates are also grouped separate from both I and II clusters. Cluster analysis revealed that Asn $\rightarrow$ Gly change in this position was not associated with the host preference as glycine position in MVCKYCGHT motif was noticed in the $\mathrm{CP}$ region of ApMV strains from different hosts including hop, elderberry, apricot, peach, Mahaleb cherry, and hazelnut.

The nucleotide sequences of MP gene of the hazelnut isolates were most similar to the sequence of apple isolate KMi2 from China (acc. no. AM490197). All these isolates formed the cluster distinct from the other apple strains which MP gene sequences were available in EMBL/GenBank database. Interestingly, that sequences of CP and MP genes of the hazelnut isolates showed maximum similarity with the corresponding fragments of different reference strains of ApMV. CP gene sequences of the Polish hazelnut isolates were most closely related to the almond strain
PAT-ITA from Italy, while the sequences of MP gene of ApMV from hazelnuts showed maximum identity to the apple isolate $\mathrm{KMi} 2$ from China.

There are several reports on variability of the $\mathrm{CP}$ gene of ApMV [11, 14, 17, 18, 27] and MP gene [14, 27]. However, for the first time, isolates of ApMV from hazelnut were characterized based on the both, CP and MP genes sequences. This is also the first report on detection and identification of ApMV in hazelnut from Poland using molecular biology techniques.

Acknowledgments This work was supported by National Science Centre Grant No. 2011/01/B/NZ9/01750.

Open Access This article is distributed under the terms of the Creative Commons Attribution 4.0 International License (http://creative commons.org/licenses/by/4.0/), which permits unrestricted use, distribution, and reproduction in any medium, provided you give appropriate credit to the original author(s) and the source, provide a link to the Creative Commons license, and indicate if changes were made.

\section{References}

1. Akbaş B, Değirmenci K (2009) Incidence and natural spread of Apple mosaic virus on hazelnut in the West Black Sea coast of Turkey and its effect on yield. J Plant Pathol 91(3):767-771

2. Alrefai RH, Shiel PJ, Domier LL, D'arcy CJ, Berger PH, Korban SS (1994) Nucleotide sequence of Apple mosaic virus coat protein gene: no homology with other Bromoviridae coat protein genes. J Gen Virol 7:2847-2850

3. Aramburu J, Rovira M (1995) Effects of apple mosaic virus (ApMV) on the growth and yield of 'Negret' hazelnut. Acta Hortic 386:565-568

4. Aramburu J, Rovira M (1998) The effects of apple mosaic ilarvirus (ApMV) on hazelnut (Corylus avellana L). J Hortic Sci Biotechnol 73:97-101

5. Aramburu J, Rovira M (2000) Incidence and natural spread of Apple mosaic ilarvirus in hazel in North-east Spain. Plant Pathol 49:423-427

6. Arli Sokmen M, Kutluk Yilmaz ND, Mennan H, Sevik MA (2005) Natural weed hosts of Apple mosaic virus in hazelnut orchards in Turkey. J Plant Pathol 87(3):239-242

7. Atanasoff D (1935) Old and new virus diseases of trees and shrubs. Phytopathol Zeitsch 8:97-223

8. Boom R, Sol CJA, Salimans MMM, Jansen CL, Wertheim-Van Dillen PME, Van Der Nordaa J (1990) Rapid and simple method for purification of nucleic acids. J Clinic Microbiol 28:495-503

9. Dhingra KL (1972) Transmission of Apple mosaic by natural root grafting. Indian J Hort 29:348-350

10. Gottlieb AR, Berbee JG (1973) Line pattern of birch caused by apple mosaic virus. Phytopathology 63:1470-1477

11. Grimová L, Winkowska L, Ryšánek P, Svoboda P, Petrzik K (2013) Reflects the coat protein variability of apple mosaic virus host preference? Virus Genes 47:119-125

12. Hunter JA, Chamberlain EE, Atkinson JD (1958) Note on the transmission of Apple mosaic by natural root grafting. New Zealand J Agricult Res 1:80-82

13. Kobyłko T, Nowak B, Urban A (2005) Incidence of Apple mosaic virus (ApMV) on hazelnut in South-East Poland. Folia Hortic 17(2):153-161

14. Lakshmi V, Hallan V, Ram R, Ahmed N, Zaidi AA, Varma A (2011) Diversity of Apple mosaic virus isolates in India based on 
coat protein and movement protein genes. Indian $\mathrm{J}$ Virol 22:44-49

15. Lee GP, Ryu KH, Kim HR, Kim CS, Lee DW, Kim JS, Park MH, Noh YM, Choi SH, Han DH, Lee CH (2002) Cloning and phylogenetic characterization of coat protein genes of two isolates of apple mosaic virus from 'Fuji' apple. Plant Pathol J 18:259-265

16. Pethybridge SJ, Wilson CR, Hay FS, Leggett GW, Sherriff LJ (2002) Mechanical transmission of Apple mosaic ilarvirus in Australian hop (Humulus lupulus) gardens. Ann App Biol 141:77-85

17. Petrzik K, Lenz O (2002) Remarkable variability of apple mosaic virus capsid protein gene after nucleotide position 141. Arch Virol 147(7):1275-1285

18. Petrzik K (2005) Capsid protein sequence gen analysis of Apple mosaic virus infecting pear. Eur J Plant Pathol 111:355-360

19. Piskornik Z, Kobyłko T, Nowak B (2002) Detection of apple mosaic virus (ApMV) on hazelnut (Corylus sp.) in Poland. Phytopathol Pol 23:31-37

20. Postman JD, Mehlenbacher SA (1994) Apple mosaic virus in hazelnut germplasm. Acta Hortic 351:601-605

21. Postman JD, Cameron HR (1987) Apple mosaic virus in U.S. filbert germplasm. Plant Dis 71:944-945
22. Ragozzino A (1980) Hazel mosaic. Acta Hort 94:375-378

23. Shiel PJ, Alrefai RH, Domier LL, Korban SS, Berger PH (1995) The complete nucleotide sequence of Apple mosaic virus RNA-3. Arch Virol 103:1247-1256

24. Shiel PJ, Berger PH (2000) The complete nucleotide sequence of apple mosaic virus (ApMV) RNA 1 and RNA 2: ApMV is more closely related to alfalfa mosaic virus than to other ilarviruses. J Gen Virol 81(1):273-278

25. Tamura K, Dudley J, Nei M, Kumar S (2007) MEGA4: Molecular Evolutionary Genetics Analysis. (MEGA) software version 4.0. Mol Biol Evol 24:1596-1599

26. Tzanetakis IE, Martin RR (2005) First report of strawberry as a natural host of Apple mosaic virus. Plant Dis 89:31

27. Valasevich N, Cieślińska M, Kolbanova E (2015) Molecular characterization of Apple mosaic virus isolates from apple and rose. Eur J Plant Pathol 141:839-945

28. Wong SM, Horst RK (1993) Purification and characterization of an isolate of apple mosaic virus from rose in the USA. J Phytopathol 139:33-47 